\title{
Efektivitas Metode Talking Stick Dalam Meningkatkan Hasil Belajar Matematika Pada Peserta Didik Kelas V Mi Al-Irsyad Leteang Desa Tenggelang Kecamatan Luyo Kabupaten Polewali Mandar
}

\author{
Mahmuddin \\ Fakultas Tarbiyah dan Ilmu Keguruan \\ Institut Agama Islam DDI Polewali Mandar \\ J1. Gatot Soebroto Kelurahan Madatte Kecamatan Polewali Kab. Polewali Mandar
}

\begin{abstract}
ABSTRAK
Penelitian ini mendeskripsikan tentang efektifitas penggunaan metode pembelajaran talking stick dalam meningkatkan hasil belajar Matematika pada peserta didik kelas V MI Al-Irsyad Leteang Desa Tenggelang Kecamatan Luyo Kabupaten Polewali Mandar. Jenis penelitian ini merupakan penelitian eksperiment, dimana penerapan atau penggunaan metode pembelajaran talking stick diuji cobakan dalam pembelajaran Matematika dengan pendekatan kuantitatif. Desain penelitian yang digunakan adalah "One Group Pretest-Posttest Design". Teknik sampling yang digunakan dalam penelitian ini adalah teknik total sampling dengan jumlah 30 orang peserta didik. Tekhnik pengumpulan data yang digunakan adalah observasi dan pelaksanaan tes. Data-data yang telah dikumpulkan selanjutnya dianalisis secara statistik deskriptif dan analisis statistik inferensial berupa analisis perbandingan dengan menggunakan uji-t.

Hasil penelitian menunjukkan bahwa rata-rata nilai hasil belajar matematika yang dicapai oleh peserta didik kelas V MI Al-Irsyad Leteang Desa Tenggelang Kecamatan Luyo Kabupaten Polewali Mandar Tahun Pelajaran 2018/2019 pada tes awal (pre-test) adalah 49,73 yang berada pada kategori sedang. Setelah diberi perlakuan dengan menerapkan metode pembelajaran Talking Stick, hasil belajar matematika peserta didik mengalami peningkatan secara signifikan menjadi 76,45 pada tes akhir (post-test). Dengan demikian, metode pembelajaran talking stick efektif digunakan dalam meningkatkan hasil belajar matematika pada peserta didik kelas V MI Al-Irsyad Leteang Desa Tenggelang Kecamatan Luyo Kabupaten Polewali Mandar.
\end{abstract}

Kata Kunci : Efektivitas, Metode Pembelajaran Talking Stick, Hasil Belajar Matematika

\section{PENDAHULUAN}

\section{A. Latar Belakang Masalah}

Dalam usaha peningkatan mutu pendidikan telah dilakukan berbagai perubahan dan pembaharuan di berbagai bidang yang erat kaitannya dengan pendidikan. Seperti perubahan dan penyempurnaan kurikulum, peningkatan pengetahuan dan keterampilan guru-guru bidang studi melalui pelatihan. Salah satu upaya untuk meningkatkan pengetahuan dan keterampilan guru-guru 
bidang studi ini tentu dengan melalui proses belajar. Bukan hanya peserta didik yang harus belajar, tetapi pendidik/guru juga perlu belajar untuk meningkatkan pengetahuan dan wawasannya.

Belajar pada hakikatnya adalah proses interaksi terhadap semua situasi yang ada di sekitar individu. Menurut James O. Whittaker dalam Supriyono Ahmad, belajar dapat didefenisikan sebagai proses dimana tingkah laku ditimbulkan atau diubah melalui latihan atau pengalaman. ${ }^{1}$ Belajar dapat dipandang sebagai proses yang diarahkan kepada tujuan dan proses berbuat melalui berbagai pengalaman. Belajar juga merupakan proses melihat, dan mengamati sesuatu. Perubahan tingkah laku tersebut menyangkut perubahan yang bersifat pengetahuan (kognitif), dan keterampilan (psikomotorik) maupun yang menyangkut nilai dan sikap (afektif). ${ }^{2}$

Kegiatan pembelajaran dilakukan oleh dua orang pelaku, yaitu guru dan peserta didik. Prilaku guru adalah mengajar dan prilaku peserta didik adalah belajar. Prilaku mengajar dan prilaku belajar tersebut terkait dengan bahan pembelajaran. ${ }^{3}$ Bahan pembelajaran dapat berupa pengetahuan, nilainilai kesusilaan, seni, agama, sikap, dan keterampilan.

Hubungan antara guru, peserta didik, dan bahan ajar bersifat dinamis dan kompleks. Untuk mencapai keberhasilan dalam kegiatan pembelajaran, terdapat beberapa komponen yang dapat menunjang yaitu komponen tujuan, komponen materi, komponen strategi belajar mengajar, dan komponen evaluasi. Masing-masing komponen tersebut saling terkait dan saling mempengaruhi satu sama lain.

Keempat komponen pembelajaran tersebut harus diperhatikan oleh guru dalam memilih dan menentukan metode-metode pembajaran apa yang akan digunakan dalam kegiatan pembelajaran. Oleh karena itu, dalam proses pembelajaran, peran guru dalam memilih strategi pembelajaran diperlukan guna mencapai keberhasilan program pembelajaran. Pembelajaran dapat berhasil dengan baik apabila guru dapat merancang sistem pembelajaran yang mampu membuat peserta didik dapat belajar secara efektif, khususnya pada mata pelajaran Matematika.

Matematika merupakan salah satu mata pelajaran yang sangat penting untuk dipelajari dan diketahui oleh setiap peserta didik. Menurut James dalam Suherman, Matematika adalah ilmu tentang logika mengenai bentuk, susunan, besaran, dan konsep-konsep yang berhubungan satu sama lain dengan jumlah yang banyak dan terbagi dalam tiga bidang, yaitu aljabar, analisis, dan geometri. ${ }^{4}$

Berdasarkan hasil observasi awal dan wawancara langsung yang telah dilakukan di MI AlIrsyad Leteang Desa Tenggelang Kecamatan Luyo Kabupaten Polewali Mandar, ditemukan fakta bahwa banyak diantara peserta didik yang kurang semangat ketika belajar Matematika dengan alasan bahwa Matematika itu sulit dan sering membuat mereka jenuh ketika belajar, sehingga kebanyakan peserta didik tidak suka dengan pelajaran tersebut. Salah satu penyebabnya, mungkin karena metode

\footnotetext{
${ }^{1}$ Supriyono Ahmad, Psikologi belajar (Jakarta: Aneka Cipta, 2012), h. 126

${ }^{2}$ Siregar, Eveline, dan Nara Hartini, Teori Belajar dan Pembelajaran (Jakarta: Ghalia Indonesia, 2010), h. 3

${ }^{3}$ Rusman, Model-Model Pembelajaran: Mengembangkan Profesionalisme Guru (Jakarta: Raja Grafindo Persada, 2011), h. 1

${ }^{4}$ Jica Suherman, Strategi Pembelajaran Matematika Kontemporer (Bandung: Universitas Pendidikan Indonesia, 2011), h. 18
} 
yang digunakan oleh guru dalam mengajar kurang tepat sehingga membuat peserta didik kurang nyaman dalam belajar dan akhirnya cepat jenuh. ${ }^{5}$

Dengan adanya kondisi seperti itu, maka diperlukan suatu strategi pembelajaran yang dapat menciptakan suasana belajar yang efektif dan menyenangkan bagi peserta didik untuk membantunya dalam memahami pelajaran, khususnya mata pelajaran matematika agar hasil belajarnya memuaskan. Salah satu strategi pembelajaran yang dimaksud adalah dengan menggunakan metode talking stick, yaitu metode pembelajaran dengan bantuan tongkat, artinya siapapun yang memegang tongkat wajib menjawab pertanyaan dari guru setelah peserta didik mempelajari materi pokoknya.

Metode talking stick ini mirip dengan permainan dalam olah raga, seperti estapet karena metode pembelajaran ini menggunakan media tongkat/kayu. Ketika tongkat bergulir/berpindah dari peserta didik yang satu ke peserta didik yang lain, akan diiringi lagu (sambil bernyanyi). Menurut Agus Suprijono bahwa langkah akhir dari metode talking stick adalah guru memberikan kesempatan kepada peserta didik melakukan refleksi terhadap materi yang telah dipelajarinya. Guru memberi ulasan terhadap seluruh jawaban yang diberikan peserta didik, selanjutnya bersama-sama peserta didik merumuskan kesimpulan. ${ }^{6}$

Berdasarkan hasil penelitian yang relevan yang telah dilakukan oleh beberapa peneliti sebelumnya, disimpulkan bahwa metode pembelajaran ini sangat menyenangkan karena dapat meningkatkan motivasi peserta didik dalam belajar. Dalam hal ini peserta didik harus siap dan berusaha untuk bisa menjawab pertanyaan yang diajuakn guru jika peserta didik tersebut telah memegang tongkatnya.

Dari uraian latar belakang di atas, peneliti terdorong untuk mengadakan penelitian dengan judul "Efektivitas Penggunaan Metode Pembelajaran Talking Stick Dalam Meningkatkan Hasil Belajar Matematika Pada Peserta Didik Kelas V MI Al-Irsyad Leteang Desa Tenggelang Kecamatan Luyo Kabupaten Polewali Mandar", dimana di sekolah tersebut cocok bagi penulis untuk mengadakan penelitian ini, karena menurut informasi yang diperoleh dari sekolah tersebut bahwa metode pembelajaran talking stick ini belum pernah digunakan sebelumnya. Oleh sebab itu, penulis merasa tertarik untuk mengadakan penelitian eksperimen terhadap penggunaan atau penerapan metode pembelajaran talking stick ini.

\section{B. Rumusan Masalah}

1. Bagaimana hasil belajar matematika yang dicapai peserta didik sebelum dan sesudah penggunaan metode pembelajaran talking stick di kelas V MI Al-Irsyad Leteang Desa Tenggelang Kecamatan Luyo Kabupaten Polewali Mandar?

2. Apakah penggunaan metode pembelajaran talking stick efektif dalam meningkatkan hasil belajar matematika pada peserta didik kelas V MI Al-Irsyad Leteang Desa Tenggelang Kecamatan Luyo Kabupaten Polewali Mandar?

\footnotetext{
${ }^{5}$ Hasil observasi awal dan wawancara langsung dengan Kepala Sekolah di MI Al-Irsyad Leteang Desa Tenggelang Kecamatan Luyo Kabupaten Polewali Mandar, pada tanggal 19 Februari 2019.

${ }^{6}$ Agus Suprijono, Cooperative Learning Teori dan Aplikasi Paikem (Yogyakarta: Pustaka Pelajar, 2011), h. 109
} 


\section{Tujuan Penelitian}

1. Untuk mengetahui hasil belajar matematika yang dicapai peserta didik sebelum dan sesudah penggunaan metode pembelajaran talking stick di kelas V MI Al-Irsyad Leteang Desa Tenggelang Kecamatan Luyo Kabupaten Polewali Mandar.

2. Untuk mengetahui efektif tidaknya penggunaan metode pembelajaran talking stick dalam meningkatkan hasil belajar matematika pada peserta didik kelas V MI Al-Irsyad Leteang Desa Tenggelang Kecamatan Luyo Kabupaten Polewali Mandar.

\section{Manfaat Penelitian}

1. Bagi peserta didik, dengan menggunakan metode talking stick maka setiap peserta didik dapat aktif dalam kelas, baik untuk bertanya maupun untuk menjawab pertanyaan yang dilemparkan oleh guru, peserta didik juga akan terbiasa untuk belajar lebih awal (belajar dahulu) dan tidak cepat jenuh.

2. Bagi guru, dapat menerapkan metode pembelajaran talking stick sebagai salah satu langkah baru dalam proses pembelajaran, khususnya pada mata pelajaran matematika dengan menguji kesiapan peserta didik dan melatih peserta didik untuk aktif dalam proses pembelajaran, khusunya pada pembelajaran matematika.

3. Bagi sekolah, memberikan informasi bagi pihak sekolah untuk dapat dijadikan bahan pertimbangan agar metode pembelajaran talking stick ini dapat diterapkan pada mata pelajaran yang sesuai sebagai salah satu upaya meningkatkan mutu pembelajaran di sekolah.

\section{E. Hipotesis Penelitian}

Berdasarkan rumusan masalah yang telah dikemukakan dan landasan teori yang digunakan, maka hipotesis penelitian ini dapat dirumuskan: "Metode pembelajaran talking stick efektif digunakan dalam meningkatkan hasil belajar matematika pada peserta didik kelas V MI Al-Irsyad Leteang Desa Tenggelang Kecamatan Luyo Kabupaten Polewali Mandar”.

\section{METODE PENELITIAN}

Ditinjau dari segi desain penelitian, maka penelitian ini merupakan penelitian eksperiment, dimana penerapan atau penggunaan metode pembelajaran talking stick diuji cobakan dalam pembelajaran Matematika dengan tujuan untuk mengetahui efektifitas dari penerapan metode pembelajaran talking stick dalam pembelajaran matematika pada peserta didik kelas V MI Al-Irsyad Leteang Desa Tenggelang Kecamatan Luyo Kabupaten Polewali Mandar.

Desain penelitian yang digunakan adalah "One Group Pretest-Posttest Design" yang hanya melibatkan satu kelompok saja tanpa kelompok pembanding. Jadi penelitian ini adalah penelitian eksperimen dengan melibatkan satu kelompok kelas (sampel) yang diambil secara utuh sebagai kelompok eksperimen sekaligus sebagai kelas kontrol, yaitu kelas V MI Al-Irsyad Leteang Desa Tenggelang Kecamatan Luyo Kabupaten Polewali Mandar. Pendekatan yang digunakan dalam penelitian ini adalah pendekatan kuantitatif. 
Penelitian ini dilaksanakan di MI Al-Irsyad Leteang Desa Tenggelang Kecamatan Luyo Kabupaten Polewali Mandar pada Tahun Pelajaran 2018/2019 pada bulan Maret sampai dengan Mei 2019. Populasi dalam penelitian ini adalah seluruh peserta didik kelas V MI Al-Irsyad Leteang pada Tahun Pelajaran 2018/2019 dengan jumlah peserta didik 30 orang. Karena jumlah populasi dalam penelitian ini hanya 30 orang yang kurang dari 100, maka teknik pengambilan sampel yang digunakan dalam penelitian ini adalah total sampling, yaitu pengambilan sampel secara penuh dimana seluruh anggota populasi diambil untuk dijadikan sampel penelitian.

Ada 2 (dua) variabel penelitian yang akan dikaji dalam penelitian ini, yaitu:

1. Efektivitas penggunaan metode pembelajaran talking stick dalam proses pembelajaran matematika.

2. Hasil belajar matematika.

Teknik yang digunakan dalam pengumpulan data adalah teknik observasi dan teknik pelaksanaan tes. Data keikutsertaan dan keaktifan peserta didik selama mengikuti kegiatan proses pembelajaran matematika yang dilaksanakan dalam penelitian ini, diambil atau dikumpulkan dengan menggunakan lembar pedoman observasi.

Sedangkan data tentang hasil belajar matematika yang dicapai peserta didik dikumpulkan melalui pelaksanaan tes hasil belajar dengan menggunakan lembar tes tertulis yang berisi soal-soal matematika berbentuk pilihan ganda dengan jumlah soal 20 nomor yang di ambil dari buku paket Matematika kelas V. Pelaksanaan tes ini bertujuan mengukur kemampuan peserta didik baik sebelum maupun sesudah perlakuan untuk mengetahui efektif tidaknya metode yang telah diterapkan. Pelaksanaan tes dilakukan dua kali, yaitu pre-test dan post-test.

Teknik atau metode analisis data yang digunakan untuk menganalisis data-data yang diperoleh dalam penelitian ini adalah teknik analisis statistik deskriptif dan analisis statistik inferensial berupa analisis perbandingan dengan menggunakan uji-t. Statistik inferensial digunakan untuk menguji hipotesis penelitian.

Uji hipotesis penelitian dalam penelitian ini menggunakan program SPSS 19> Adapun uji hipotesis dalam program SPSS 19 ini adalah uji Independet Sample T Test untuk menguji efektifitas penerapan model pembelajaran Talking Stick dalam meningkatkan hasil belajar matematika kelas V MI Al-Irsyad Leteang Kecamatan Luyo Kabupaten Polewali Mandar. Uji-t digunakan untuk menganalisis perbedaan nilai rata-rata hasil post-test dengan nilai rata-rata hasil pre-test pada taraf signifikan $\alpha=0,05$.

Jadi dampak atau efektifitas dari penggunaan metode pembelajaran talking stick dalam proses pembelajaran Matematika di kelas V MI Al-Irsyad Leteang ditentukan dengan cara membandingkan skor hasil tes awal (pre-test) dengan tes akhir (post-test).

\section{HASIL PENELITIAN DAN PEMBAHASAN}

\section{A. Hasil Analisis Statistik Deskriptif}

\section{Analisis Statistik Deskriptif untuk Data Nilai Hasil Tes Awal}

Hasil analisa deskriptif kuantitatif dari data hasil belajar matematika kelas V MI Al-Irsyad Leteang yang diperoleh melalui tes awal (pre-test) dapat diuraikan pada tabel 1 sebagai berikut: 
Tabel 1. Deskripsi Distribusi Hasil Belajar Matematika yang Diperoleh Peserta Didik Kelas V MI Al-Irsyad Leteang pada Tes Awal

\begin{tabular}{|c|c|}
\hline Statistik & Nilai Statistik \\
\hline Ukuran Sampel & 30 \\
Skor Maksimum & 65 \\
Skor Minimum & 35 \\
Rentang Skor & 30 \\
Skor rata-rata & 49,74 \\
Median & 50,00 \\
Modus & 45 \\
Standar deviasi & 8.378 \\
Variansi & 70,199 \\
\hline
\end{tabular}

Sumber: Data primer (hasil tes awal), 2019

Bedasarkan data-data pada Tabel 1 dapat dijelaskan bahwa nilai rata-rata hasil belajar matematika yang dicapai peserta didik kelas V MI Al-Irsyad Leteang tahun pelajaran 2018/2019 adalah 49,74 dari skor ideal 100. Nilai tertinggi atau skor maksimum yang diperoleh peserta didik adalah 65 dan nilai terendah atau skor minimum adalah 35 sehingga rentang skor adalah 30 . Median yang dihasilkan adalah 50,00 dan modusnya adalah 45 . Standar deviasi yang dihasilkan dari data nilai hasil belajar matematika yang dicapai peserta didik kelas V MI Al-Irsyad Leteang adalah sebesar 8,378 kemudian variansi data tersebut adalah 70,199.

Berdasarkan hasil nilai Pre-Test untuk kelas V MI Al-Irsyad Leteang yang merupakan kelas sampel penelitian diperoleh nilai yang dapat dilihat pada tabel 2 pada daftar distribusi frekuensi yang dikelompokkan dengan lima kategori sebagai berikut:

Tabel 2. Distribusi Frekuensi dan Persentase Nilai Hasil Belajar Matematika yang Diperoleh Peserta Didik Kelas V MI Al-Irsyad Leteang pada Tes Awal

\begin{tabular}{|c|c|c|c|}
\hline Interval nilai & Kategori & Frekuensi & Persentase (\%) \\
\hline $0-32$ & Sangat Rendah & 0 & 0,00 \\
\hline $33-64$ & Rendah & 26 & 86,67 \\
\hline $65-76$ & Sedang & 4 & 13,33 \\
\hline $77-88$ & Tinggi & 0 & 0,00 \\
\hline $89-100$ & Sangat Tinggi & 0 & 0,00 \\
\hline \multicolumn{2}{|c|}{ Jumlah } & $\mathbf{3 0}$ & $\mathbf{1 0 0 , 0 0}$ \\
\hline
\end{tabular}

Sumber: Data primer (hasil tes awal), 2019

Dari daftar distribusi pada tabel 2 dapat diuraikan bahwa tidak ada peserta didik kelas V MI Al-Irsyad Leteang yang meperoleh nilai antara $0-32$ yang dikategorikan sangat rendah dengan persentase sebesar $0,00 \%$. Peserta didik yang memperoleh nilai antara $33-64$ dengan kategori rendah yaitu sebanyak 26 orang dengan persentase sebesar $86,67 \%$, peserta didik yang memperoleh nilai antara 65 - 76 dengan kategori sedang sebanyak 4 orang dengan pesentase 13,33\%. 
Berdasarkan hasil belajar di atas untuk kelas V MI Al-Irsyad Leteang dapat disimpulkan bahwa hasil belajar yang diperoleh peserta didik kelas kelas V MI Al-Irsyad Leteang pada Pre-Test masih banyak yang memperoleh kategori rendah dengan jumlah frekuensi 26 dari 30 orang peserta didik atau dengan persentase $86,67 \%$ dari skor ideal sebesar $100 \%$.

Kemudian untuk melihat persentase ketuntasan belajar matematika pada peserta didik kelas V MI Al-Irsyad Leteang pada tes awal (sebelum penerapan Metode Pembelajaran Talking Stick) dapat dilihat pada Tabel 3 berikut:

Tabel 3. Deskripsi Ketuntasan Belajar Matematika Peserta Didik Kelas V MI Al-Irsyad Leteang pada Tes Awal

\begin{tabular}{|c|c|c|c|}
\hline Interval Skor & Kategori & Frekuensi & Persentase (\%) \\
\hline $0-64$ & Tidak Tuntas & 26 & 86,67 \\
$65-100$ & Tuntas & 4 & 13,33 \\
\hline \multicolumn{2}{|c|}{ Jumlah } & $\mathbf{3 0}$ & $\mathbf{1 0 0 , 0 0}$ \\
\hline
\end{tabular}

Sumber: Data primer (hasil tes awal), 2019

Berdasarkan data pada Tabel 3 di atas dapat diketahui bahwa jumlah peserta didik kelas V MI Al-Irsyad Leteang pada tes awal yang berada pada kategori tidak tuntas adalah sebanyak 26 orang dengan persentase sebesar 86,67 \% dengan nilai terendah sebesar 35 dan nilai tertinggi sebesar 64 . Sedangkan jumlah peserta didik yang masuk kategori tuntas adalah sebanyak 4 orang atau sebesar $13,33 \%$ dengan perolehan nilai masing-masing 65 .

Data tersebut memperlihatkan bahwa peserta didik kelas V MI Al-Irsyad Leteang Desa Tenggelang Kecamatan Luyo Kabupaten Polewali Mandar pada tes awal tahun pelajaran 2018/2019 lebih banyak memperoleh nilai dengan ketegori tidak tuntas daripada kategori tuntas, sebelum diterapkannya metode pembelajaran Talking Stick.

\section{Analisis Statistik Deskriptif untuk Data Nilai Hasil Tes Akhir}

Hasil analisa deskriptif kuantitatif dari data hasil belajar matematika kelas V MI Al-Irsyad Leteang yang diperoleh melalui tes akhir setelah menerapkan metode pembelajaran Talking Stick diperoleh data seperti diuraikan pada Tabel 4 sebagai berikut:

Tabel 4. Deskripsi Distribusi Hasil Belajar Matematika yang Diperoleh Peserta Didik Kelas V MI Al-Irsyad Leteang Kabupaten Polewali Mandar pada Tes Akhir

\begin{tabular}{|c|c|}
\hline Statistik & Nilai Statistik \\
\hline Ukuran Sampel & 30 \\
Skor Maksimum & 95 \\
Skor Minimum & 50 \\
Rentang Skor & 45 \\
Skor rata-rata & 76,45 \\
Median & 80,00 \\
Modus & 85 \\
Standar deviasi & 12,352
\end{tabular}




\section{Sumber: Data primer (hasil tes akhir), 2019}

152,578

Bedasarkan Tabel 4 dapat dijelaskan bahwa nilai rata-rata hasil belajar matematika yang dicapai peserta didik kelas V MI Al-Irsyad Leteang tahun pelajaran 2018/2019 setelah diterapkannya metode pembelajaran Talking Stick adalah sebesar 76,45 dari skor ideal 100. Nilai tertinggi atau skor maksimum yang diperoleh peserta didik adalah 95 dan nilai terendah atau skor minimum adalah 50 sehingga rentang skor adalah 45. Median yang dihasilkan adalah 80,00 dan modusnya adalah 85 . Standar deviasi yang dihasilkan dari data nilai hasil belajar matematika yang dicapai peserta didik kelas V MI Al-Irsyad Leteang adalah sebesar 12,352 dengan nilai variansi sebesar 152,578.

Berdasarkan data nilai hasil Post-Test yang diperoleh peserta didik kelas V MI Al-Irsyad Leteang sebagai kelas sampel penelitian pada mata pelajaran matematika diperoleh daftar distribusi nilai matematika yang dikelompokkan dengan lima kategori seperti diperlihatkan pada Tabel 5 sebagai berikut:

Tabel 5. Distribusi Frekuensi dan Persentase Nilai Hasil Belajar Matematika yang Diperoleh Peserta Didik Kelas V MI Al-Irsyad Leteang pada Tes Akhir

\begin{tabular}{|c|c|c|c|}
\hline Interval nilai & Kategori & Frekuensi & Persentase (\%) \\
\hline $0-32$ & Sangat Rendah & 0 & 0,00 \\
\hline $33-64$ & Rendah & 2 & 6,67 \\
\hline $65-76$ & Sedang & 7 & 23,33 \\
\hline $77-88$ & Tinggi & 15 & 50,00 \\
\hline $89-100$ & Sangat Tinggi & 6 & 20,00 \\
\hline \multicolumn{2}{|c|}{ Jumlah } & $\mathbf{3 0}$ & $\mathbf{1 0 0 , 0 0}$ \\
\hline
\end{tabular}

Sumber: Data primer (hasil tes akhir), 2019

Dari daftar distribusi pada Tabel 5 dapat diuraikan bahwa tidak ada peserta didik yang memperoleh nilai antara 0 - 32 dengan kategori sangat rendah, jumlah peserta didik yang memperoleh nilai hasil belajar matematika antara 33 - 64 yang berkategori rendah sebanyak 2 orang dengan persetase $6,67 \%$. Kemudian jumlah peserta didik yang memperoleh nilai hasil belajar matematika antara 65-76 dengan kategori sedang adalah sebanyak 7 orang dengan persentase sebesar 23,33\%. Peserta didik yang memperoleh nilai hasil belajar matematika antara 77 - 88 dengan kategori tinggi sebanyak 15 orang dengan persentase sebesar $50 \%$, dan peserta didik yang memperoleh nilai hasil belajar matematika antara 89-100 dengan kategori sangat tinggi sebanyak 6 orang dengan persentase $20 \%$.

Berdasarkan nilai hasil belajar matematika yang diperoleh peserta didik kelas V MI Al-Irsyad Leteang tersebut di atas dapat disimpulkan bahwa hasil belajar matematika yang diperoleh peserta didik pada kelas tersebut setelah diterapkan metode pembelajaran Talking Stick mengalami peningkatan, yaitu sebanyak 7 orang memperoleh nilai hasil belajar matematika pada kategori sedang dengan persentase $23,33 \%$ dan yang peroleh nilai hasil belajar matematika berkategori tinggi sebanyak 15 orang dengan persentase $50 \%$, serta ada 6 orang atau sebesar $20 \%$ peserta didik yang memperoleh nilai hasil belajar matematika dengan kategori sangat tinggi. 
Kemudian untuk melihat persentase ketuntasan belajar matematika pada peserta didik kelas V MI Al-Irsyad Leteang Desa Tenggelang Kecamatan Luyo Kabupaten Polewali Mandar pada tes akhir (sesudah penerapan Metode Pembelajaran Talking Stick) tahun pelajaran 2018/2019 dapat dilihat pada Tabel 6 berikut:

Tabel 6. Deskripsi Ketuntasan Belajar Matematika pada Peserta Didik Kelas V MI Al-Irsyad Leteang pada Tes Akhir

\begin{tabular}{|c|c|c|c|}
\hline Skor & Kategori & Frekuensi & Persentase (\%) \\
\hline $0-64$ & Tidak Tuntas & 2 & 6,67 \\
$65-100$ & Tuntas & 28 & 93,33 \\
\hline \multicolumn{2}{|c|}{ Jumlah } & $\mathbf{3 0}$ & $\mathbf{1 0 0 , 0 0}$ \\
\hline
\end{tabular}

Sumber: Data primer (hasil tes akhir), 2019

Berdasarkan data pada Tabel 6 di atas dapat diketahui bahwa, jumlah peserta didik pada tes akhir (post - test) yang berada pada kategori tidak tuntas dalam belajar matematika adalah sebanyak 2 orang dengan persentase sebesar $6,67 \%$, dengan nilai terendah 50 dan nilai tertinggi 60 . Sedangkan jumlah peserta didik yang masuk kategori tuntas dalam belajar matematika adalah sebanyak 28 orang atau sebesar 93,33\% dengan nilai terendah 65 dan nilai tertinggi 95.

Data-data tersebut memperlihatkan bahwa jumlah peserta didik kelas V MI Al-Irsyad Leteang Kabupaten Polewali Mandar pada tes akhir (post-test) tahun pelajaran 2018/2019 yang tuntas dalam belajar matematika setelah penerapan metode pembelajaran Talking Stick adalah jauh lebih besar dari pada jumlah peserta didik yang belum tuntas. Hal ini membuktikan bahwa setelah diterapkannya metode Talking Stick dalam pembelajaran matematika maka hasil belajar matematika yang dicapai peserta didik kelas V MI Al-Irsyad Leteang Desa Tenggelang Kecamatan Luyo Kabupaten Polewali Mandar mengalami peningkatan ketuntasan sebesar $80 \%$.

\section{B. Hasil Analisis Statistik Inferensial}

Adapun uji hipotesis yang digunakan yaitu uji Independent Sample T Test dimana menguji signifikansi perbedaan rata-rata (mean) antara 2 kelompok data yaitu antara nilai hasil belajar matematika yang dicapai peserta didik pada tes awal dan nilai hasil belajar matematika yang dicapai peserta didik pada tes akhir setelah diberi perlakuan berupa penerapan metode Talking Stick dalam pembelajaran matematika. Pada pengujian hipotesis penelitian ini, digunakan taraf signifikan $95 \%$ atau dengan nilai $\alpha=0,05$.

Jadi, data yang akan diujikan dalam uji hipotesis ini adalah rata-rata nilai hasil belajar matematika yang dicapai peserta didik kelas V MI Al-Irsyad Leteang pada tes akhir (post-test) atau setelah diberi perlakuan dengan metode pembelajaran Talking Stick dan rata-rata nilai hasil belajar matematika yang dicapai peserta didik pada tes awal (pre-test) tanpa menggunakan metode Talking Stick (menggunakan metode ceramah). Rata-rata hasil Pre-Test dan Post-Test yang dicapai peserta didik kelas V MI Al-Irsyad Leteang adalah sebagai berikut:

1. Rata-rata hasil matematika pada Pre-test

2. Rata-rata hasil matematika pada Post-test
$=49,737$

$=76,44737$ 
Hasil belajar matematika yang dicapai peserta didik kelas V MI Al-Irsyad Leteang dari Pretest ke Post-test mengalami peningkatan sebesar 26,711 \%. Akan tetapi, sesuai dengan teknik analisis data statistik yang digunakan dalam pengujian hipotesis (sebelum melakukan analisis inferensial) maka terlebih dahulu dilakukan uji persyaratan analisis terhadap data penelitian yang diperoleh. Uji persyaratan analisis yang dimaksud adalah uji normalitas dan uji homogenitas yang secara rinci diuraikan sebagai berikut.

\section{Uji Normalitas Data}

Untuk pengujian normalitas kelompok data, digunakan uji Kolmogorov-Smirnov dengan taraf signifikan $\alpha=0,05$. Uji normalitas ini bertujuan untuk melihat apakah data nilai hasil belajar matematika yang dicapai peserta didik adalah berdistribusi normal atau tidak.

a. Uji Normalitas Data Nilai Hasil Pre-Test

Hasil perhitungan pengujian normalitas data nilai hasil Pre-Test pada peserta didik kelas V MI Al-Irsyad Leteang pada taraf signifikan $\alpha=0,05$ untuk uji Komogorov-Smirnov diperoleh nilai signifikansi $=0,078$.

Rumus hipotesis sebagai berikut:

$\mathrm{H}_{0} \quad$ : Data Pre-Test berdistribusi normal

$\mathrm{H}_{1}$ : Data Pre-Test tidak berdistribusi normal

Menurut Priyatno, jika nilai signifikansi $>0,05$, maka data berdistribusi normal dan jika nilai signifikansi $<0,05$, maka data tidak berdistribusi secara normal. ${ }^{7}$

Karena hasil analisis data "Pre-Test" memiliki nilai signifikansi 0,078 yang lebih dari 0,05 $(0,078>0,05)$ maka $\mathrm{H}_{0}$ diterima. Berarti data hasil belajar matematika yang dicapai peserta didik kelas V MI Al-Irsyad Leteang pada tes awal (pre-test) adalah berdistribusi normal.

b. Uji Normalitas Data Nilai Hasil Post-Test

Hasil perhitungan pengujian normalitas data nilai hasil Post-Test pada peserta didik kelas V MI Al-Irsyad Leteang pada taraf signifikan $\alpha=0,05$ untuk uji Komogorov-Smirnov diperoleh nilai signifikansi $=0,06$.

Rumus hipotesis sebagai berikut:

$\mathrm{H}_{0}$ : Data Post-Test berdistribusi normal

$\mathrm{H}_{1} \quad$ : Data Post-Test tidak berdistribusi normal

Karena hasil analisis data "Post-test" memiliki nilai signifikansi sebesar 0,06 yang lebih besar dari $0,05(0,060>0,05)$ maka $\mathrm{H}_{0}$ diterima. Berarti data hasil belajar matematika yang dicapai peserta didik kelas V MI Al-Irsyad Leteang pada tes akhir (post-test) adalah berdistribusi normal.

\section{Uji Homogenitas}

Uji homogenitas ini bertujuan untuk mengetahui apakah variansi dari dua kelompok data dalam penelitian ini memiliki variansi yang sama (homogen) atau tidak. Adapun data yang akan diuji homogenitas adalah rata-rata nilai hasil belajar matematika yang dicapai peserta didik pada tes akhir (post-test) dan rata-rata nilai hasil belajar matematika yang dicapai pada tes awal (pre-test).

${ }^{7}$ Duwi Priyatno, 5 Jam Belajar Olah Data dengan SPSS 19 (Yogyakarta: Andi Offset, 2009), h. 46 
Uji homogenitas yang digunakan adalah pengujian ANOVA atau analisis varians dengan taraf signifikansi 0,05. Pada uji homogenitas ini digunakan bantuan komputer dalam proses perhitungan dengan program SPSS 19.

Rumus Hipotesis dalam bentuk kalimat adalah:

$\mathrm{H}_{0}$ : Variansi data nilai hasil belajar matematika pada tes awal sama dengan variansi data nilai hasil belajar matematika pada tes akhir.

$\mathrm{H}_{1}$ : Variansi data nilai hasil belajar matematika pada tes awal tidak sama dengan variansi data nilai hasil belajar matematika pada tes akhir.

Rumusan hipotesis statistik yang digunakan adalah:

$$
\begin{aligned}
& \mathrm{H}_{0}: \mu_{\text {Awal }}=\mu_{\text {Akhir }} \\
& \mathrm{H}_{1}: \mu_{\text {Awal }} \neq \mu_{\text {Akhir }}
\end{aligned}
$$

Keterangan:

$\mu_{\text {Awal }}=$ Rata-rata nilai hasil tes awal

$\mu_{\text {Akhir }}=$ Rata-rata nilai hasil tes akhir

Adapun kriteria pengujian berdasarkan signifikansi menurut Priyatno adalah sebagai berikut: ${ }^{8}$ Jika signifikansi $>0,05$, maka $\mathrm{H}_{0}$ diterima.

Jika signifikansi $<0,05$, maka $\mathrm{H}_{0}$ ditolak.

Hasil perhitungan uji homogenitas rata-rata nilai hasil belajar matematika yang dicapai peserta didik pada tes awal (pre-test) dan pada tes akhir (post-test) dengan menggunakan program SPSS 19 diperoleh nilai signifikan $=0,520$.

Menurut Priyatno, asusmi dalam pengujian ANOVA adalah bahwa varian kelompok data adalah sama atau homogen. Kriteria pengujiannya, yaitu jika signifikansi $<0,05$ maka varian kelompok data tidak sama. Sebaliknya, jika signifinkansi $>0,05$, maka varian kelompok data adalah sama. Dari output pada tabel Test of Homogeneity of Variances dapat dilihat bahwa signifikansi yang dihasilkan sebesar 0,52 yang lebih besar dari 0,05 (0,52>0,05), maka $\mathrm{H}_{0}$ diterima. Jadi dapat disimpulkan bahwa variansi kedua kelompok data, yaitu kelompok data hasil tes awal dan kelompok data hasil tes akhir adalah sama atau homogen.

\section{Pengujian Hipotesis}

Uji hipoteseis yang digunakan adalah uji Independent Sample $T$ Test untuk menguji signifikansi perbedaan mean dua kelompok data pada taraf signifikan 95\% $(\alpha=0,05)$ dan juga menggunakan Uji Paired Sampel T-test untuk menguji perbedaan rata-rata antara dua sampel yang berpasangan, yaitu yang dimaksud dalam penelitian ini adalah perbedaan rata-rata antara hasil PreTest dan Post-Test pada taraf signifikan $95 \%(\alpha=0,05)$.

Pengujiian hipotesis ini adalah untuk mengetahui apakah terjadi peningkatan nilai hasil belajar matematika secara signifikan atau tidak dan menjawab hipotesis penelitian yang menyatakan "Metode pembelajaran talking stick efektif digunakan dalam meningkatkan hasil belajar Matematika pada peserta didik kelas V MI Al-Irsyad Leteang Desa Tenggelang Kecamatan Luyo Kabupaten

${ }^{8}$ Duwi Priyatno, Ibid., h. 87 
Polewali Mandar". Peningkatan nilai yang dimaksud adalah rata-rata nilai Post-Test - rata-rata nilai Pre-Test atau selisih rata-rata antara nilai Post-Test dan Pre-Test.

Dalam analisis pengujian hipotesis, rumusan hipotesis statistik dalam bentuk kalimat yang digunakan adalah:

$\mathrm{H}_{0}$ : Tidak ada perbedaan rata-rata nilai hasil belajar matematika yang dicapai pada post-test dan pada pre-test.

$\mathrm{H}_{1}$ : Ada perbedaan rata-rata nilai hasil belajar matematika yang dicapai pada post-test dan pada pre-test.

Adapun kriteria pengujiannya adalah sebagai berikut:

Jika $-\mathrm{t}_{\text {tabel }} \leq \mathrm{t}_{\text {hitung }} \leq \mathrm{t}_{\text {tabel, }}$ maka $\mathrm{H}_{\mathrm{o}}$ diterima.

Jika $-\mathrm{t}_{\text {hitung }}<-\mathrm{t}_{\text {tabel }}$ atau $\mathrm{t}_{\text {hitung }}>\mathrm{t}_{\text {tabel, }}$, maka $\mathrm{H}_{0}$ ditolak

Kriteria pengujian berdasarkan signifikansi:

Jika signifikansi > 0,05, maka $\mathrm{H}_{0}$ diterima.

Jika signifikansi $<0,05$, maka $\mathrm{H}_{0}$ ditolak

Kriteria keputusan:

Jika nilai $\mathrm{t}_{\text {hitung }}$ lebih besar dari nilai $\mathrm{t}_{\text {tabel }}$ maka $\mathrm{H}_{1}$ diterima dan $\mathrm{H}_{0}$ ditolak. Hal ini berarti bahwa hipotesis penelitian diterima. Berdasarkan dari hasil analisis olah data menggunakan SPSS 19 diperoleh hasil pengujian hipotesis yaitu $t_{\text {hitung }}=-11,404$ dengan $\mathrm{df}=29$ dan signifikansi $=0,000$. $\mathrm{T}_{\text {tabel }}$ dapat dilihat pada tabel statistik pada signifikansi $0,05: 2=0,025$ (uji 2 sisi) dengan derajat kebebasan (df) $n-1=30-1=29$. Hasil yang diperoleh untuk $t$ tabel sebesar $-2,026$.

Karena harga $\mathrm{t}_{\text {hitung }}=-11,404<\mathrm{t}_{\text {tabel }}=-2,028$ dan nilai signifikasnsi $0,000<0,05$, maka $\mathrm{H}_{0}$ ditolak secara statistik karena harga $t_{\text {hitung }}$ tersebut jatuh pada daerah penolakan $\mathrm{H}_{0}$. Artinya hipotesis $\mathrm{H}_{0}$ ditolak dan hipotesis $\mathrm{H}_{1}$ diterima.

Berdasarkan dari hasil analisis di atas bahwa harga $t_{\text {hitung }}<$ harga $t_{\text {tabel }}$ dan menunjukkan bahwa $\mathrm{H}_{0}$ ditolak dan $\mathrm{H}_{1}$ diterima ini membuktikan bahwa dari hasil analisis uji hipotesis menyatakan nilai rata-rata hasil Post-Test $(76,45)$ lebih tinggi secara signifikan dari pada nilai rata-rata hasil Pre-Test $(49,74)$ yang diperoleh peserta didik kelas V MI Al-Irsyad Leteang Desa Tenggelang Kecamatan Luyo Kabupaten Polewali Mandar.

Dengan demikian, nilai rata-rata hasil belajar matematika yang dicapai pada post-test mengalami peningkatan yang signifikan secara statistik dengan nilai rata-rata $=76,45$. Sehingga dapat ditarik kesimpulan bahwa hipotesis penelitian yang telah dirumuskan dalam penelitian ini, yaitu "Metode pembelajaran talking stick efektif digunakan dalam meningkatkan hasil belajar matematika pada peserta didik kelas V MI Al-Irsyad Leteang Desa Tenggelang Kecamatan Luyo Kabupaten Polewali Mandar" adalah diterima secara statistik.

\section{PENUTUP}

\section{A. Simpulan}

Berdasarkan hasil penelitian dan analisis data yang telah dilakukan maka dapat disimpulkan bahwa rata-rata nilai hasil belajar matematika yang dicapai oleh peserta didik kelas V MI Al-Irsyad Leteang Desa Tenggelang Kecamatan Luyo Kabupaten Polewali Mandar Tahun Pelajaran 2018/2019 
pada tes awal (pre-test) adalah 49,73 yang berada pada kategori sedang. Setelah diberi perlakuan dengan menerapkan metode pembelajaran Talking Stick, hasil belajar matematika peserta didik mengalami peningkatan secara signifikan menjadi 76,45 pada tes akhir (post-test). Dengan demikian, metode pembelajaran talking stick efektif digunakan dalam meningkatkan hasil belajar Matematika pada peserta didik kelas V MI Al-Irsyad Leteang Desa Tenggelang Kecamatan Luyo Kabupaten Polewali Mandar.

\section{B. Saran}

1. Pada guru matematika SD/MI, khususnya guru matematika MI Al-Irsyad Leteang Desa Tenggelang Kecamatan Luyo Kabupaten Polewali Mandar kiranya dapat menerapkan metode pembelajaran Talking Stick dalam meningkatkan hasil belajar matematika.

2. Kiranya dapat dijadikan sebagai salah satu metode pembelajaran di sekolah, karena metode Talking Stick ini tidak hanya cocok digunakan pada mata pelajaran matematika tetapi dapat juga digunakan pada mata pelajaran lain.

\section{DAFTAR PUSTAKA}

Ahmad, Supriyono. Psikologi belajar. Jakarta: Aneka Cipta, 2012.

Ali, Zainuddin. Metode Penelitian Kuantitatif dan Kualitatif. Jakarta: Gramedia Pustaka Utama, 2009.

Anggoro, M. Toha. Metodologi Penelitian. Bandung: Alfabeta, 2010.

Arikunto, Suharsimi. Prosedur Penelitian Suatu Pendekatan Prkatik. Jakarta: Rineka Cipta, 2010.

Asdar, Andi Asniar. Efektivitas Model Pembelajaran Kooperatif Tipe STAD Dalam Pembelajaran Matematika. Skripsi. Pare-Pare: UMPAR, 2011.

Darmadi, Hamid. Metode Penelitian Pendidikan. Cetakan ke-2. Bandung: Alfabeta, 2011.

Depdiknas. Kamus Besar Bahasa Indonesia Edisi Ketiga. Jakarta: Balai Pustaka, 2005.

Hamalik, Oemar. Proses Belajar Mengajar. Jakarta: Bumi Aksara, 2010.

Hamzah, B. Uno. Model-Model Pembelajaran. Jakarta: Bumi Aksara, 2012.

Harjanto. Perencanaan Pengajaran. Jakarta: Rineka Cipta, 2010.

Ismail. Kapita Selekta Pembelajaran Matemetika. Jakarta: Universitas Tebuka, 2010.

Priyatno, Duwi. 5 Jam Belajar Olah Data dengan SPSS 19. Yogyakarta: Andi Offset, 2009.

Purwanto. Instrumen Penelitian Sosial dan Pendidikan. Yogyakarta: Pustaka Pelajar, 2010.

Purwanto. Evaluasi Hasil Belajar. Jakarta: Pustaka Belajar, 2011.

Riduwan. Metode dan Teknik Menyusun Proposal Penelitian. Bandung: Alfabeta, 2009.

Rusman. Model-Model Pembelajaran: Mengembangkan Profesionalisme Guru. Jakarta: Raja Grafindo Persada, 2011.

Sanjaya, Wina. Strategi Pembelajaran Berorientasi Standar Proses Pendidikan. Jakarta: Kencana Prenada Media Group, 2010.

Setyosari, Punaji. Metode Penelitian Pendidikan dan Pengembangan. Jakarta: Kencana, 2012. 
Siregar, Eveline, dan Nara Hartini. Teori Belajar dan Pembelajaran. Jakarta: Ghalia Indonesia, 2010.

Siregar, Syofian P. Statistik Deskriptif Untuk Penelitian. Jakarta: Raja Grafindo Persada, 2010.

Sudjadi. Kiat Pendidikan Matematika di Indonesia. Jakarta: Direktorat Jenderal Pendidikan Nasional, 2008.

Sudjana, Nana. Tuntunan Penyusunan Karya Ilmiah. Jakarta: Sinar Baru, 2009.

Suherman, Jica. Strategi Pembelajaran Matematika Kontemporer. Bandung: Universitas Pendidikan Indonesia, 2011.

Sugiyono. Metode Penelitian Pendidikan Pendekatan Kuantitatif, Kualitatif, dan R \& D. Bandung: Alfabeta, 2014.

Suprijono, Agus. Cooperative Learning Teori dan Aplikasi Paikem. Yogyakarta: Pustaka Pelajar, 2011.

Syah, Muhibbin. Psikologi Belajar. Jakarta: Raja Grafindo Persada, 2009.

Yusri. Statistika Sosial: Aplikasi dan Interpretasi. Yogyakarta: Graha Ilmu, 2009. 